\title{
Ethics policies, perceived social responsibility, and positive work attitude
}

Research Article

\author{
Sean Valentine ${ }^{1 *}$ and Lynn Godkin² \\ 'Department of Management, University of North Dakota, \\ United States of America \\ 'Department of Management and Marketing, Lamar University, \\ United States of America
}

Abstract: Employers that emphasise ethics often encourage a variety of positive work-related outcomes, yet the manner in which different ethics policies and corporate social responsibility (CSR) enhance employee attitudes is still subject to investigation. Consequently, this study explored how ethics training and an ethics code work with perceived social responsibility to encourage positive feelings about work. Using survey data collected from 781 individuals employed in an education-based health science centre, the results indicated that hours of ethics training and a shared ethics code operated through perceived social responsibility to enhance a positive work attitude, measured as job satisfaction and an intention to stay. Creating an ethical environment and emphasising socially responsible business practices should encourage employees to respond more favourably to the workplace. In particular, companies should use ethics codes and training to emphasise CSR, thus enhancing employees' work attitudes.

Keywords: corporate social responsibility; ethics policies/programs; job attitudes

(C) De Gruyter Open Sp. z 0.0.

\section{INTRODUCTION}

Ethical and socially responsible companies often utilise different policies to introduce standards that guide ethics throughout the organisation (Weaver, 2004; Weaver et al., 1999a; White and Lam, 2000). However, '...having standards is not enough, a company must make the standards understood, and ensure their proper dissemination within the organisational structure' (Palmer and Zakhem, 2001: 83). Consequently, ethics policies also communicate important ethical values, practices, and norms so that employees understand workplace expectations, thus influencing their personal ethics (James, 2000; Kaptein, 2009). A variety of programs can be used such as committees/task forces, ethics-based communication channels, reporting mechanisms/hotlines, ethics officers/ employees, governance, and periodic ethics audits (Ferrell et al., 2008; Kaptein, 2009, 2011a; McAlister et al., 2005; Minkes et al., 1999; Trevino and Nelson, 2011; Weaver et al., 1999c; White and Lam, 2000).

Much research shows that different ethics policies can encourage individual and organisational interest in and attention to ethics (Adams et al., 2001; Delaney and Sockell, 1992; Kaptein, 2009; Schwepker and Good, 2007; Schwepker and Hartline, 2005; Wotruba et al., 2001). For instance, use of ethics policies can lead to higher ethical performance (McCabe et al., 1996; Singhapakdi and Vitell,1991), increased organisational pride, enhanced corporate identity, a stronger moral climate, greater employee socialisation, clearer behavioural constraints (Chua and Rahman, 2011), institutionalised expectations/norms (Adams et al., 2001; Farrell and Farrell, 1998; Fritz et al., 1999; Valentine and Barnett, 2002), and increased CSR (Valentine and Fleischman, 2008). The resulting ethical environment also yields higher job satisfaction and organisational commitment (Deshpande, 1996; Hunt et al., 1989; Trevino et al., 1998; Valentine and Barnett, 2003; Vitell and Davis, 1990). Ethics policies can also be directly related to work attitudes (Valentine, 2009; Valentine and Fleischman, 2008).

Note: An earlier version of this study was presented at 2012 Irish Academy of Management Conference and received the Best Paper Award for the Business Ethics and Sustainability Track. 
Despite these findings, the manner in which ethics programs, a work environment that emphasises ethics and social responsibility, and job attitudes are interrelated is still subject to investigation. For instance, some research cast doubt on the effectiveness of certain ethics programs to create positive change in organisations (Adam and Rachman-Moore, 2004; Akaah and Riordan, 1989; Allen and Davis, 1993; Callan, 1992; Chonko and Hunt, 1985; Eyun-Jung et al., 2012; Higgs-Kleyn and Kapelianis, 1999; Izzo, 2000; Kaptein, 2011b; Kaptein and Schwartz, 2008; Schwartz, 2000; Stevens, 2008; Waples et al., 2009; Weaver et al., 1999c). In addition, previous research has generated mixed findings when examining the relationships among ethics policies, organisational ethics, and work attitudes, with some studies finding that ethics programs operate through ethical context and CSR to influence individual thoughts and feelings (Schwepker and Hartline, 2005; Valentine and Barnett, 2003), and others reporting that both ethics policies and organisational ethics directly impact work attitudes and outcomes (Somers, 2001; Valentine, 2009; Valentine and Fleischman, 2008; Valentine et al., 2010). Finally, few studies have explored the potential role of CSR as an important contextual variable in organisations, as well as how such an environment is related to ethics policies and work attitudes. This suggests that more research is needed to clarify how social responsibility might be developed to enhance important work outcomes.

These realisations raise several key questions: (1) Do ethics policies enhance perceptions that an employer is socially responsible?, (2) Do perceptions of social responsibility enhance how employees feel about work?, and (3) Do ethics policies impact positive work attitudes by enhancing perceived social responsibility (full mediation)?, or do they directly impact work attitudes in concert with perceived social responsibility (partial mediation)? Consequently, the purpose of this study was to investigate, using a full mediation model, the impact of ethics training hours and a shared ethics code on the perceptions of social responsibility; the impact of perceived social responsibility on a positive job attitude, comprised of job satisfaction and an intention to stay, was also investigated. In addition, the relationships between the ethics programs, social responsibility, and a positive job attitude were explored in a separate partial mediation model. Figure 1 provides an overview of the proposed relationships of this study. The results contribute to the ethics literature by identifying how organisational ethics can be utilised to improve how individuals view their employers, thus enhancing important work outcomes. Of equal importance are the practical implications that ethics and social responsibility can be developed to enhance how employees respond to their immediate work environment.

Figure 1. Hypothesised relationships

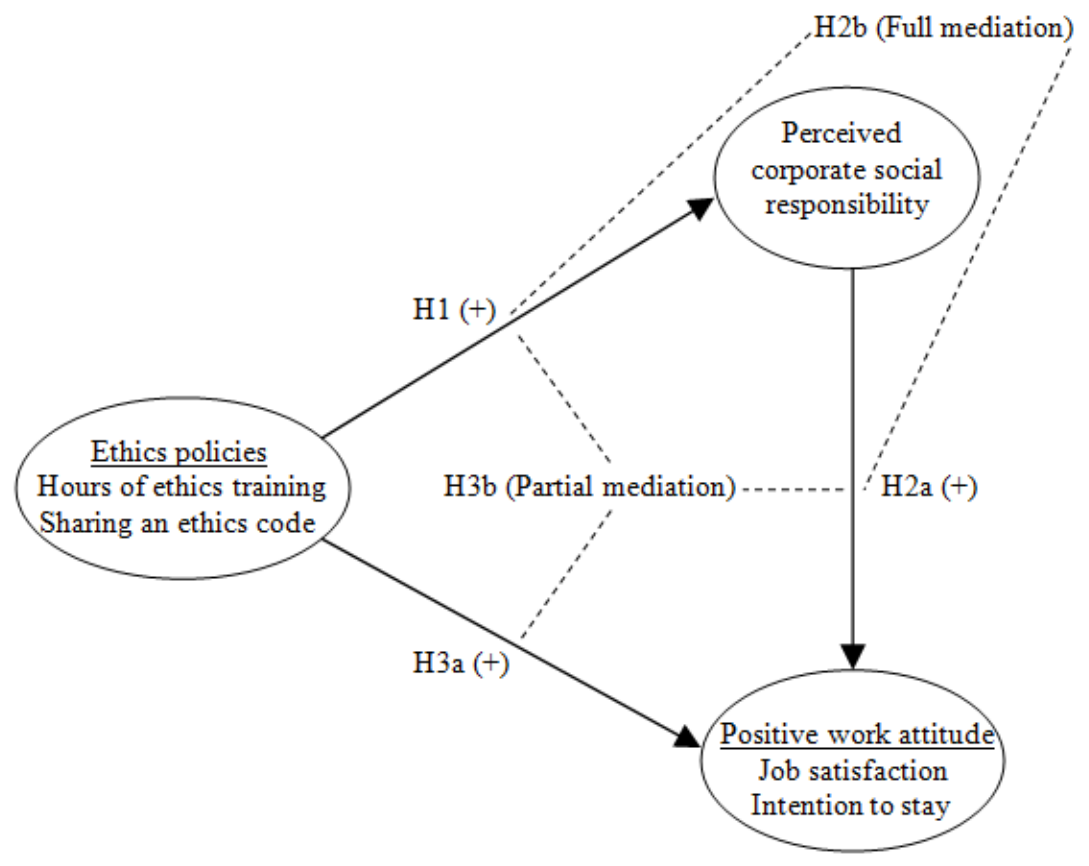




\section{ETHICS POLICIES AND PERCEIVED SOCIAL RESPONSIBILITY}

Ethics training and codes of conduct are two common ethics policies (Cleek and Leonard, 1998; James, 2000; LeClair and Ferrell, 2000; Palmer and Zakhem, 2001; Schwartz, 2001; Stevens et al., 2005; Wells and Schminke, 2001). Ethics training is provided to employees to enhance their understanding of ethical decision making and make them aware of the company's ethical values to improve their own reasoning (Frisque and Kolb, 2008; Knouse and Giacalone, 1997). 'Effective training and education efforts are often focused on helping employees understand ethical standards and their application to workplace decisions' (LeClair and Ferrell, 2000: 313). Some of this knowledge can be provided by covering a company's codes of conduct, as well as the formalised ethical positions expressed in mission/vision statements, business objectives, or policies (Minkes et al., 1999; Stevens et al., 2005; Trevino and Nelson, 2011; Wells and Schminke, 2001). Further understanding can be instilled by covering the ethical dilemmas employees face on the job and providing them advise about how they should manage these challenges (Knouse and Giacalone, 1997; White and Lam, 2000). In addition, McAlister et al. (2005: 138) state that:

Such training can educate employees about the firm's policies and expectations, relevant laws and regulations, and general social standards. Training programs can make employees aware of available resources, support systems, and designated personnel who can assist them with ethical and legal advice. Training also can help empower employees to ask tough questions and make ethical decisions.

Similar to ethics training, codes of ethics are statements that serve as guides about a company's principles, duties, and expectations for appropriate employee behaviour (Cassell et al., 1997; Chua and Rahman, 2011; Collett, 1998; Kaptein, 2004). According to Schwartz (2001: 248), an ethics code is 'a written, distinct, and formal document which consists of moral standards used to guide employee or corporate behavior.' Codes of ethics can shape conduct by expressing organisational norms, values, core beliefs, and moral concerns (Adams et al., 2001; Farrell and Farrell, 1998; Sims, 1991; Trevino, 1986; Wotruba et al., 2001). Ethics codes also reflect the core principles for managerial behaviour and encourage employees to become part of ethical leadership in their companies (Stevens, 2008).

Ethics codes are also an integral part of the organisational communication system (Collett, 1998) and enable companies to practice some degree of self-regulation (Kaptein, 2008; Schwartz, 2001), often strengthening organisational identity and reputation (Adams et al., 2001; Chua and Rahman, 2011). Using codes of ethics is thus a dominant way of standardising and promoting ethical beliefs across the organisation. Such normative characteristics of codes ' ...ensure, through a process of internalisation , that members of organisations are aware of their role(s) in a social situation and to behave appropriately in accordance with the specified standards of conduct. The emphasis is on social obligation, which means that members conform not because it serves their individual interests but because they are obligated to do so' (Chua and Rahman, 2011: 323). The purpose of ethics codes is to support an ethical organisational environment (Adams et al., 2001; Akaah and Lund, 1994; Peterson, 2002; Schwartz, 2001; Sims, 1991; Trevino and Nelson, 2011; Valentine and Barnett, 2002; Weaver et al., 1999a).

Both ethics training and codes of conduct can enhance employees' generalised perceptions of organisational ethics and other positive practices in the workplace (Adams et al., 2001; Valentine and Barnett, 2003; Valentine and Fleischman, 2004, 2008). In particular, the internal ethical environment, the collection of cultural and climate-based components of work (i.e., corporate values, social mores, ethical behaviours, and other normative elements) related to ethics (Hunt et al., 1989; Trevino et al., 1998; Valentine and Barnett, 2007), is generally stronger when a company has well-developed ethics policies (Adams et al., 2001; Chua and Rahman, 2011; Kaptein, 2011a; Schwartz, 2001; Valentine and Barnett, 2002; Weaver et al., 1999a). For example, Singhapakdi and Vitell (1991) found a positive relationship between codes of ethics and perceptions of ethics problems, and another study determined that public relation professionals working for organisations that had an ethics statement were more likely to behave ethically (Eyun-Jung et al., 2012). Peterson (2002) found unethical behaviour and unethical climates to be stronger when codes were absent. Further, a number of studies show that the presence, sharing, and enforcement of ethics codes, as well as the use of ethics training, can increase employee beliefs about organisational ethics (Adams et al., 2001; Schwepker and Hartline, 2005; Somers, 2001; Valentine, 2009; Valentine and Barnett, 2002; Valentine and Fleischman, 2004; Valentine et al., 2010). 
Related to ethical environment is a company's focus on CSR. Social responsibility involves a firm's commitment to efforts that satisfy that basic economic, legal, ethical, and philanthropic interests of its various stakeholders and society as a whole (Carroll, 1979; Ferrell et al., 2008; McAlister et al., 2005; Trevino and Nelson, 2011), thus garnering greater legitimacy for the organisation and enhanced ethical congruence with stakeholder expectations (Wood, 1991; Zenisek, 1979). If these activities are developed and implemented strategically, they can improve business and community conditions (i.e., enhanced corporate reputation, reduced risk, better stakeholder relations) by '...focusing on the achievement of both corporate and social goals and recognising the broad groups to which business has an obligation' (McAlister et al., 2005: 4). It therefore stands to reason that ethics training and codes of conduct should also play a prominent role in the development of an environment where CSR is valued and practiced. For instance, Kaptein and Schwartz (2008: 113) claimed that an ethic code specifies 'a set of prescriptions developed by and for a company to guide present and future behaviour on multiple issues of at least its managers and employees toward one another, the company, external stakeholders and/or society in general,' providing support for the notion that these documents should enhance CSR. In addition, 'producing a code of ethics or updating one helps to generate positive reputational effects as it can project a more favourable corporate and social image' (Chua and Rahman, 2011: 323), encouraging perceptions among stakeholders that an employer is ethical and socially-driven. Previous research indeed shows that various ethical programs are associated with increased perceptions that an organisation is socially responsible (Valentine and Fleischman, 2008). Consequently, the following hypothesis is presented:

Hypothesis 1: Ethics policies (hours of ethics training and sharing an ethics code) are associated with increased perceptions of social responsibility.

\section{PERCEIVED SOCIAL RESPONSIBILITY AND A POSITIVE WORK ATTITUDE (FULL MEDIATION)}

Based on the theories of dissonance (Viswesvaran and Deshpande, 1996; Viswesvaran et al., 1998), psychological contracts (O'Donohue and Nelson, 2009; Sims, 1991, 1994), and work fit (Herrbach and Mignonac, 2007; Schwepker, 1999; Sims and Keon, 1997; Sims and Kroeck, 1994), organisational ethics and social responsibility are expected to enhance work attitudes. For instance, ethical values/climates contribute to constructive social exchanges among employees, resulting in stronger psychological contracts between them (Valentine et al., 2002), lower work-related conflict and ambiguity, and increased satisfaction (Jaramillo et al., 2006; Moser, 1988). Employees are also more committed to employers that are recognised as being ethical (Fritz et al., 1999; Herndon et al., 2001; Hunt et al., 1989; Kelley and Dorsch, 1991; Koonmee et al., 2010; Trevino et al., 1998; Valentine and Barnett, 2003; Valentine et al., 2002). Further, greater job satisfaction is reported by employees who believe their leaders and organisations support ethical conduct (e.g., Deshpande, 1996; Jaramillo et al., 2006; Herndon et al., 2001; Koh and Boo, 2001; Koonmee et al., 2010; Pettijohn et al., 2008; Valentine, 2009; Viswesvaran and Deshpande, 1996; Viswesvaran et al., 1998; Vitell and Davis, 1990). Finally, individuals' intentions to stay with an employer (or to quit) are impacted by organisational ethics (Herndon et al., 2001; Mulki et al., 2009; Valentine et al., 2006, 2011).

A firm's level of CSR should also influence work attitudes. Social identity theory suggests that employees seek membership in socially responsible organisations because such affiliation can enhance the way they feel about themselves (Turker, 2009). This is accomplished through a process called identity attractiveness, comprised of identity similarity, a factor that involves individuals being more content in situations or groups that are considered desirable, and identity distinctiveness, a factor that conveys the positive uniqueness of the organisational environment (Kim et al., 2010). 'Briefly, it can be claimed that an employee's enhancing social identity, as a result of being a member of a reputable organisation, will affect his or her work attitudes' (Turker, 2009: 191). If employees are given an opportunity to participate in CSR, role theory can be used to explain how work attitudes are enhanced because employees participate in activities that are self-enhancing (Kim et al., 2010). Ethically-minded job candidates will indeed be attracted to ethical organisations because of value congruity (e.g., Cacioppe et al., 2008), and perceptions of CSR can also affect individuals' preferences for seeking employment with particular firms (Greening and Turban, 2000; Turban and Greening, 1996). 'The essential point is that an individual's attraction to and retention in a company can be at least partly explained by 
individual and organisational value matches and mismatches and that some of these matches and mismatches reside in perceptions of CSR [corporate social responsibility]' (Coldwell et al., 2008: 614).

Previous empirical research provides support for these claims. For instance, Maignan et al. (1999) using samples of marketing professionals and MBA students found that corporate citizenship resulted in different benefits such as higher employee commitment. Brammer et al. (2007) also determined that perceptions of CSR were associated with increased organisational commitment among individuals working for a financial services firm. Similar findings between social responsibility and organisational commitment were reported by Turker (2009), Kim et al. (2010), Rego et al. (2010), and Stites and Michael (2011). Using questionnaire responses gathered from various business professionals, Valentine and Fleischman (2008) concluded that perceived CSR was a key predictor of job satisfaction. Consequently, the following hypotheses regarding full mediation are presented:

Hypothesis 2a: Stronger perceptions of social responsibility are associated with a more positive work attitude.

Hypothesis 2b: Perceived social responsibility fully mediates the relationship between ethics policies (hours of ethics training/sharing an ethics code) and a positive work attitude.

\section{ETHICS POLICIES AND A POSITIVE WORK ATTITUDE (PARTIAL MEDIATION)}

Just as perceived social responsibility should enhance work attitudes, and ethics policies should also influence employees' thought and feelings about the workplace. Previous research shows that ethics '...codes and programs have been found to lead to varying levels of positive organisational outcomes under certain conditions' (Colwell et al., 2011: 47). By developing policies that introduce the importance of ethics, employees should internalise ethical principles, positively influencing the way they view their roles as productive organisational members and showing them how they can make effective contributions. Social identity processes should also drive the attractiveness of these programs because employees feel stronger affiliation with companies that have desirable and unique ethical traits. These perceptions should translate into more positive work attitudes. Consequently, when employees are given ethics training or provided a code of conduct, they should believe their personal values are more congruent with organisational norms and standards (Finegan, 2000), thus leading to positive work attitudes.

Previous research has explored these relationships. Valentine and Fleischman (2008) found that communication of an ethics code functioned with perceptions of CSR to increase job satisfaction among business professionals. Using a sample of sales and marketing professionals, Valentine (2009) also determined that hours of ethics training provided to employees worked in concert with perceived ethical environment to enhance individuals' satisfaction with their coworkers. The following hypotheses related to partial mediation are therefore presented:

Hypothesis 3a: Ethics policies (hours of ethics training and sharing an ethics code) are associated with a more positive work attitude.

Hypothesis 3b: Perceived social responsibility partially mediates the relationship between ethics policies (hours of ethics training/sharing an ethics code) and a positive work attitude.

\section{METHOD}

\section{Sample}

Using a self-report questionnaire, information was collected from individuals employed in a large, universityoperated health science centre with multiple locations in the southwestern United States. A total of 781 completed questionnaires were received from the 4,025 distributed, generating an approximate response rate of $19.4 \%$. Completed questionnaires were coded using an optical reading machine. Subjects tended to be middle-aged, white women who were relatively educated and had adequate job experience in non-supervisory, non-administrative, non-teaching (mainly business and medical) type jobs. 


\section{Measures}

Ethics policies. Two separate items were used to evaluate the health science centre's ethics policies. Ethics training was assessed with one question that asked subjects approximately how many hours of ethics training they had received in the last year. This item targeted more recent ethics training because such instruction likely plays a more immediate role in shaping individuals' attitudes (Frisque and Kolb, 2008). The availability of an ethics code was evaluated with a question that asked subjects if their company had ever shared with them an ethics code that governed work conduct in the organisation (coded as $1=$ no, $2=$ yes). This item targeted the dissemination of an ethics code rather than just its presence because effective communication efforts are known to be important predictors of code success (Kaptein, 2011b).

Perceived social responsibility. The perceived social responsibility variable was assessed with a five-item CSR scale that evaluated beliefs about the centre's support of stakeholders and beneficial business practices (Valentine and Fleischman, 2008; Valentine and Godkin, 2009). The items in this scale are 'I work for a socially responsible organisation that serves the greater community,' 'My organisation gives time, money, and other resources to socially responsible causes,' 'The organisation I work for upholds generally accepted ethical business standards,' 'My organisation takes care of its customers, employees, suppliers, and investors,' and 'I work for a firm that does its best to enhance the financial well being of its stakeholders.' These statements were evaluated with a sevenpoint scale (coded as $1=$ strongly disagree, $7=$ strongly agree), and after averaging the item values, higher composite scores suggested stronger beliefs that the organisation was socially responsible. The coefficient alpha of the measure was .85 .

Positive work attitude. Two scales were also used to assess a positive work attitude. Job satisfaction was measured with three items (Cammann et al., 1983; Rich, 1997) that were rated on a seven-point scale (coded as 1 = strongly disagree, 7 = strongly agree). The items are 'All in all, I am satisfied with my job,' 'In general, I like working at my company,' and 'In general, I don't like my job.' After reverse scoring one item and averaging the item values, higher overall scores indicated increased job satisfaction. The coefficient alpha of the scale was .82. Intention to stay was evaluated with a three-item turnover intention measure (Cammann et al., 1979; Chen et al., 1998) that was also rated on a seven-point scale (coded as $1=$ strongly disagree, $7=$ strongly agree). The statements are 'I often think of leaving the organisation,' 'It is very possible that I will look for a new job next year,' and 'If I may choose again, I will choose to work for the current organisation.' After reverse scoring two items and averaging values, higher overall scores suggested increased intentions to stay with the organisation. The scale's coefficient alpha was .82 .

Social desirability. Since impression bias can be a challenge in ethics research (Randall and Fernandes, 1991), a shortened ten-item version of the Marlowe-Crowne social desirability scale (Crowne and Marlowe, 1960; Fischer and Fick, 1993; Strahan and Gerbasi, 1972) was included in the analysis. Sample items from this scale include 'I like to gossip at times' and 'I always try to practice what I preach.' Statements were rated with the two response categories (coded as 1 = False, 2 = True), and after reverse coding five items, scores were summed for a range of 10 to 20 . Higher summated values indicated greater social desirability.

\section{Analysis}

A confirmatory factor analysis was specified in AMOS to conduct measurement checks of the perceived social responsibility and positive work attitude latent constructs, which were composed of the five CSR items and the (observed) composite scores for the job satisfaction and intention to stay variables. A single-factor model was also specified to determine if common method bias was a concern. Variable descriptive statistics and correlations were then assessed using SPSS. Finally, mediation analysis was undertaken using structural equation modelling to determine whether perceived social responsibility mediated the relationships between the ethics policy variables (hours of ethics training and sharing an ethics code) and a positive work attitude (James and Brett, 1984; James et al., 2006; Schneider et al., 2005).

\section{RESULTS}

The confirmatory factor analysis, which is presented in Figure 2, indicated that the model fit the data reasonably well $\left(\chi^{2}=91.728\right.$, d.f. $=13, p<.000, \chi^{2} /$ d.f. $\left.=7.056, \mathrm{NFI}=.964, \mathrm{IFI}=.969, \mathrm{CFI}=.969, \mathrm{RMSEA}=.088\right)$. All of the observed variables loaded effectively on the latent constructs $(p<.001)$, and the standardised regression 
weights were all above .55 . The covariance and correlation scores between the perceived social responsibility and positive work attitude constructs were .98 and .72 , respectively. Utilising the standardised regression weights for the calculations, the composite reliability scores for perceived social responsibility and positive work attitude were .85 and .81, and the variance-extracted scores were .55 and .68 . The correlation squared (.51) was lower than both of the variance-extracted scores, which indicated acceptable discriminant validity (Fornell and Larcker, 1981). Finally, a single-factor model provided undesirable fit statistics $\left(\chi^{2}=298.748\right.$, d.f. $=14, p<.000, \chi^{2} /$ d.f. $=21.339, \mathrm{NFI}=$ $.882, \mathrm{IFI}=.887, \mathrm{CFI}=.887, \mathrm{RMSEA}=.161)$, suggesting that common method bias was not an issue.

Figure 2. Confirmatory factor analysis

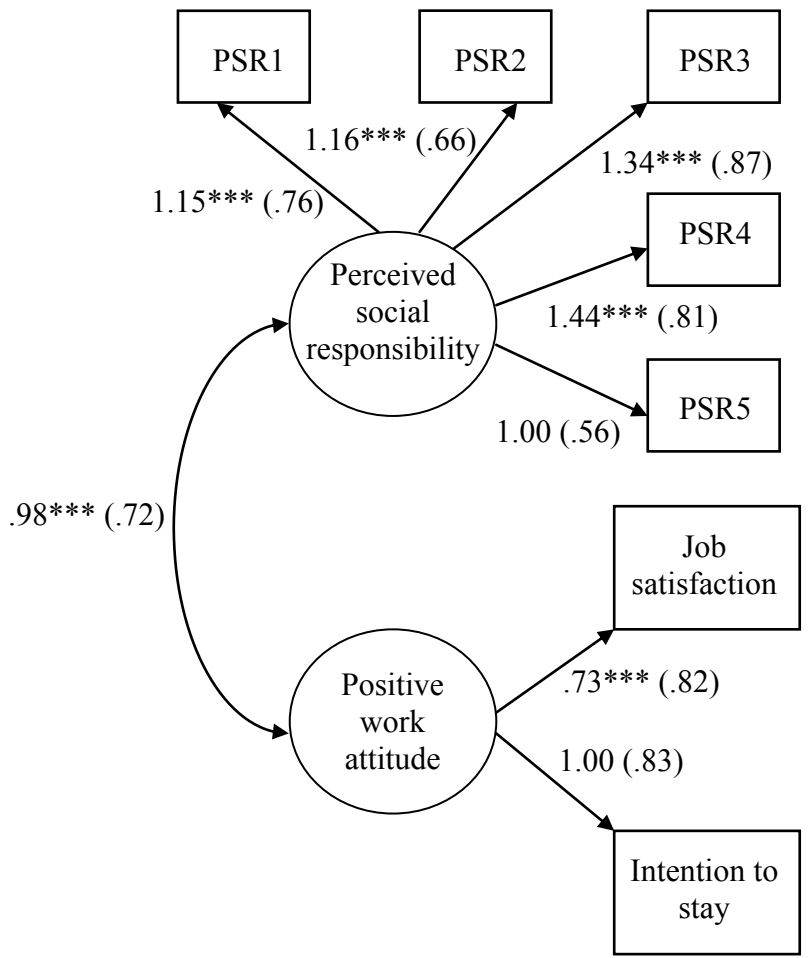

Note: ${ }^{* \star *} p<.001 ;$ standardised estimates and correlations presented in parentheses

Variable descriptive statistics and correlations are presented in Table 1. The mean values suggested that employees believed that the health science centre performed in a socially responsible manner, and that they were generally content at work. Hours of ethics training and sharing an ethics code were positively related to perceived social responsibility, job satisfaction, and intention to stay, and social responsibility was also associated with more positive work attitudes. The ethics policies were positively interrelated, as were the work attitudes. Hours of ethics training and job satisfaction were weakly related to social desirability, indicating that the scale be included as a control variable in the linear structural equation models.

Figure 3 summarises the full mediation model, which yielded sound fit statistics $\left(\chi^{2}=113.981\right.$, d.f. $=30$, $p<.000, \chi^{2} /$ d.f. $=3.799, \mathrm{NFI}=.957, \mathrm{IFI}=.968, \mathrm{CFI}=.967, \mathrm{RMSEA}=.060$ ), the observed variables were positively related to the latent constructs $(p<.001)$, and the standardised regression weights were greater than .55 . Hours of ethics training and sharing an ethics code were associated with increased perceptions of social responsibility, which provided support for Hypothesis 1 . Perceived social responsibility was also associated with a more positive work attitude, which suggests that social responsibility fully mediates the positive relationships between the ethics policies and a positive work attitude and provides support for Hypothesis $2 \mathrm{a}$ and $2 \mathrm{~b}$. Hours of ethics training was also positively related to a shared ethics code, which implies that ethics policies are developed together to enhance work outcomes. Social desirability was related to the positive work attitude and hours of ethics training variables. 
Table 1. Variable descriptive statistics and correlations

\begin{tabular}{|c|c|c|c|c|c|c|c|c|c|c|c|c|c|}
\hline Variable & $\mathbf{M}$ & SD & $\mathbf{N}$ & 1 & & 2 & & 3 & & 4 & & 5 & 6 \\
\hline 1. Hours of ethics training & 4.49 & 10.22 & 674 & -- & & & & & & & & & \\
\hline 2. Sharing an ethics code & 1.76 & .43 & 744 & .12 & ** & -- & & & & & & & \\
\hline 3. Perceived social responsibility & 4.98 & 1.23 & 725 & .11 & $\star \star$ & .22 & $\star * \star$ & -- & & & & & \\
\hline 4. Job satisfaction & 5.53 & 1.30 & 772 & .08 & * & .16 & $\star \star \star *$ & .53 & $\star \star \star$ & -- & & & \\
\hline 5. Intention to stay & 4.80 & 1.78 & 775 & .08 & * & .17 & $\star \star \star *$ & .55 & $* * *$ & .68 & $* * \star$ & -- & \\
\hline 6. Social desirability & 17.02 & 1.95 & 744 & .08 & * & .04 & & .03 & & .09 & * & .05 & -- \\
\hline
\end{tabular}

Note: ${ }^{* *} p<.001 ;{ }^{* *} p<.01,{ }^{\star} p<.05$.

Figure 3. Full mediation model. Note: ${ }^{\star \star \star} p<.001,{ }^{* \star} p<.01,{ }^{\star} p<.05$; standardised estimates and correlations presented in parentheses

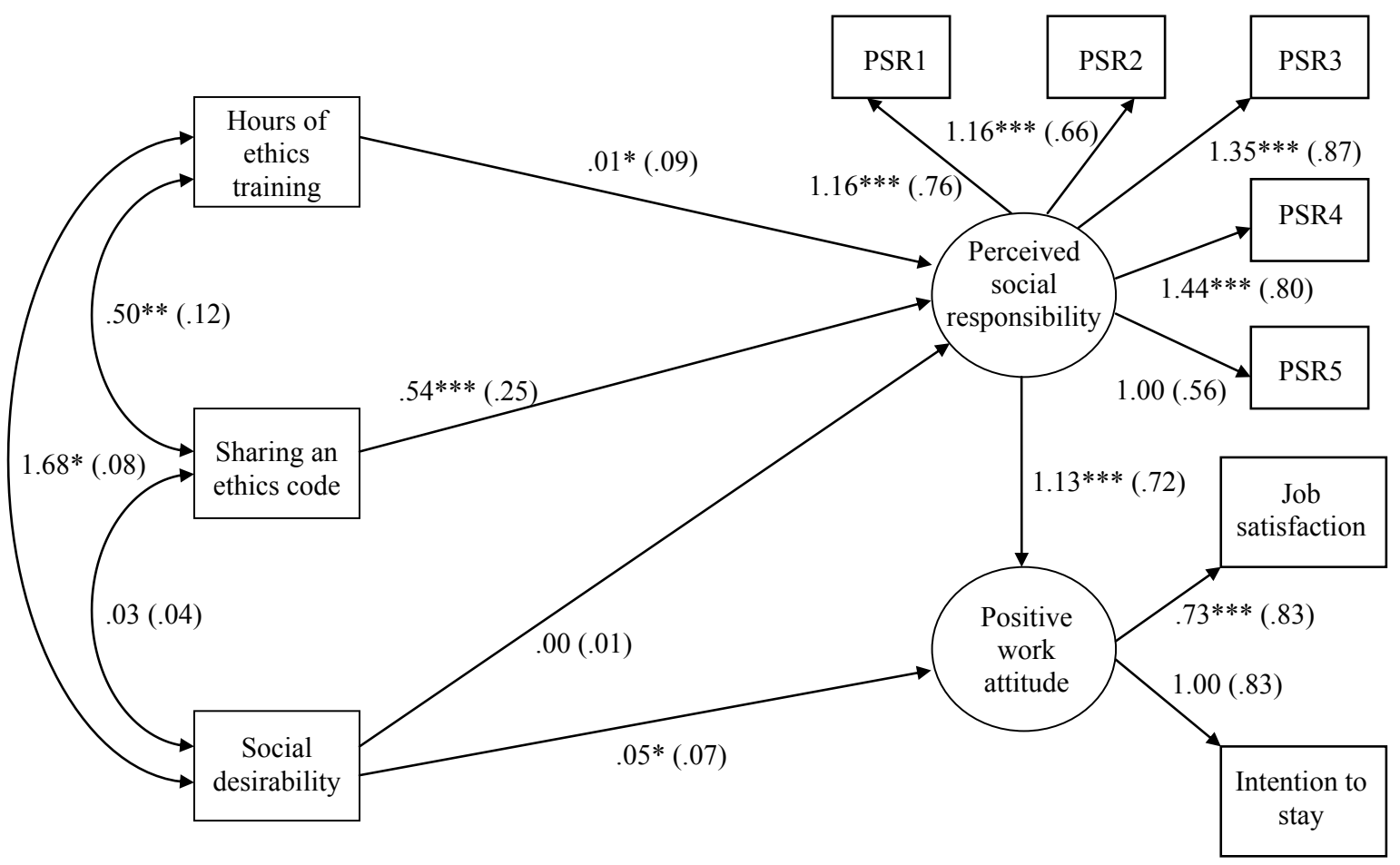

Figure 4 summarises the partial mediation model, which also provided acceptable fit statistics $\left(\chi^{2}=113.580\right.$, d.f. $=28, p<.000, \chi^{2} /$ d.f. $\left.=4.056, \mathrm{NFI}=.957, \mathrm{IFI}=.967, \mathrm{CFI}=.967, \mathrm{RMSEA}=.063\right)$, the observed variables were positively related to the latent constructs $(p<.001)$, and the standardised regression weights were greater than .55. Once again, hours of ethics training and sharing an ethics code were positively related to perceived social responsibility, and perceived social responsibility was associated with an enhanced work attitude. However, hours of ethics training and sharing an ethics code were not related to a positive work attitude in the presence of perceived social responsibility. Social desirability was again related to a positive work attitude and hours of ethics training. A chi-square difference test indicated that the partial mediation model was not significantly superior to the full mediation model $\left(\chi^{2}\right.$ difference $=.401$, d.f. difference $=2$ ), indicating that the ethics policies operated through perceived social responsibility to enhance a positive work attitude; Hypotheses $3 a$ and $3 b$ were not supported. 
Figure 4. Partial mediation model. Note: ${ }^{* *} p<.001,{ }^{* \star} p<.01,{ }^{*} p<.05$; standardised estimates and correlations presented in parentheses

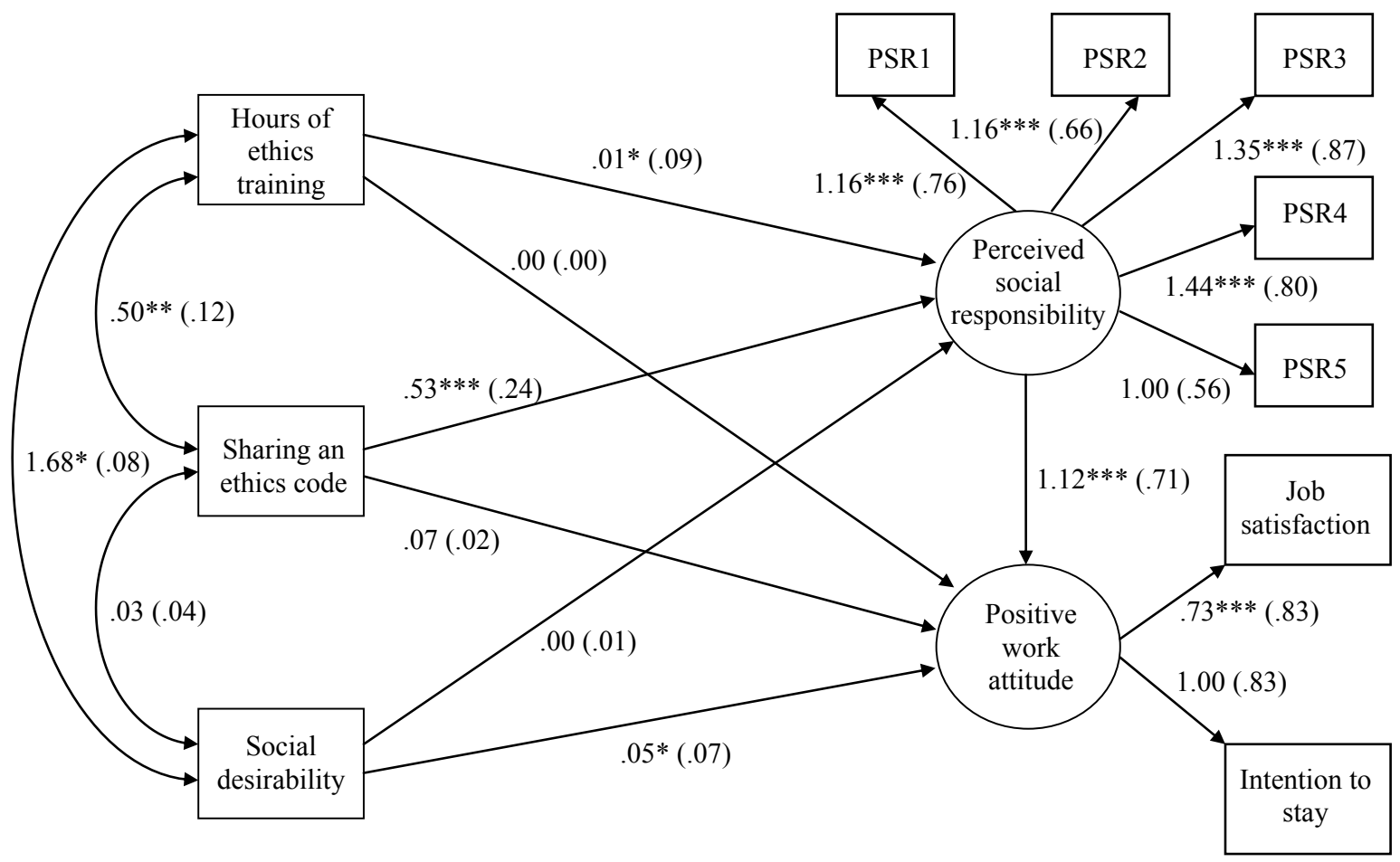

\section{DISCUSSION}

The findings indicated that two ethics policies, hours of ethics training and sharing an ethics code, were associated with stronger perceptions of social responsibility. In turn, these perceptions were associated with a more positive work attitude, comprised of job satisfaction and an intention to stay. The results also showed that the ethics policies were not related to a positive work attitude in the presence of perceived social responsibility, which suggests that these policies function through CSR to enhance positive feelings about work (or full mediation). These findings are consistent with past research showing that ethics policies and organisational ethics impact different work attitudes (e.g., Brammer et al., 2007; Deshpande, 1996; Koh and Boo, 2001; Maignan et al., 1999; Rego et al., 2010; Stites and Michael, 2011; Trevino et al., 1998; Turker, 2009; Valentine and Fleischman, 2008). However, the results shed new light on the relative order and magnitude of these relationships by examining two specific ethics policies, perceived social responsibility, and a multidimensional work attitude measure.

Company leaders should develop ethics policies that encourage greater organisational ethics and social responsibility. Based on past studies (e.g., Adams et al., 2001; Sims, 1991; Kaptein, 2009; Valentine and Barnett, 2002, 2003; Valentine and Fleischman, 2008), offering ethics training or developing codes of conduct can function symbolically to enhance employees' awareness of ethics and social responsibility. The results suggest that organisations can expect to see incremental improvements in employee job attitudes as a result of these efforts. For example, codes of conduct coupled with ethics training, management/peer influence, and increased communication can strengthen individual and organisational ethics (Adams et al., 2001; Delaney and Sockell, 1992; Jones and Kavanagh, 1996; Kaptein, 2009; LeClair and Ferrell, 2000; Minkes et al., 1999; Schwepker and Good, 2007; Valentine and Barnett, 2002; Valentine and Fleischman, 2004, 2008; Valentine et al., 2011). Such an ethical environment should also prompt greater contentedness with the workplace (Jaramillo et al., 2006; Koh and Boo, 2001; Valentine et al., 2006). When there is an agreement with a company's values, workers tend to be more supportive of institutional objectives (Rathert and Phillips, 2010), so developing an environment of ethics and social responsibility should enhance employees' connections with work. This relationship should hold true even if some employees do not share their institution's ethical position because ethical individuals will remain as productive 
members of the organisation, while those who do not support ethics will eventually leave either voluntarily or involuntarily. As such, standardisation and promotion of ethical beliefs can contribute to employees' organisational commitment (Fritz et al., 1999; Hunt et al., 1989) and increase the likelihood that they will act in an ethical manner (Eyun-Jung et al. 2012).

With regard to content, developers should incorporate material that reflects the core ethical issues that organisations and their employees face (Frisque and Kolb, 2008; Knouse and Giacalone, 1997; McAlister et al., 2005; Trevino and Nelson, 2011). Areas of interest and for improvement can be identified by using ethics audits, surveys, and employee discussion groups so that the material found in ethics training/codes is current and relevant (Ferrell et al., 2008; Kaptein, 2009; Minkes et al., 1999; Stevens, 2008; Trevino and Nelson, 2011). A series of custom-tailored sessions can also be developed to introduce employees to the ethical dilemmas they negotiate in their particular jobs. Trevino and Nelson (2011: 231) indeed claimed that:

Training should be designed to suit the group of individuals being trained. A new employee needs different training than a manager who has been with the firm for 10 years. An assembly-line worker might require only an hour of training, with regular refresher sessions, whereas a manager might require several days of training that address a variety of issues.

McAlister et al. (2005: 141) also stated that a majority of 'experts on training agree that one of the most effective methods of ethics training is involvement in resolving ethical dilemmas that relate to actual situations that employees experience in carrying out their responsibilities.' Consequently, ethics training should be more extensive than merely a one-time, overly-generalised seminar for increasing interest in ethics - an effective program should be ongoing. Sessions that increase ethics awareness should also be incorporated into other educational programs to reinforce the idea that ethics is considered an important issue.

Based on the results of this study, ethics policies should also communicate an organisation's philosophy of social performance. Doing so should effectively convey to employees the importance of CSR for building positive relationships with key stakeholders. Opportunities for volunteering, community support, and sustainability, as well as a company's current social performance efforts, could also be highlighted in ethics training and codes of conduct to encourage greater interest in ethics and social responsibility.

Ethics codes have been used to encouraging effect (Adams et al., 2001; Colwell et al., 2011; Eyun-Jung et al., 2012; McCabe et al., 1996; Schwartz, 2001; Singhapakdi and Vitell, 1991), but certain conditions might enhance the success of these programs. For example, the more tangible and intangible resources expended developing (Baker et al., 2006; Herndon et al., 2001; Hunt et al., 1989; Trevino et al., 1998), installing, implementing, communicating (Helin and Sandström, 2007; Kaptein, 2011b; Sims,1991; Stevens et al., 2005; Weaver et al., 1999b), and integrating (Weaver et al., 1999a, 1999b) a code of ethics into the organisation, the greater the likelihood that employees will respond favourably to work. Ethics codes must also be visible enough to influence employee perceptions (Adams et al., 2001; Wotruba et al., 2001). Therefore, company leaders need to effectively communicate the organisation's ethical philosophy and review ethics codes frequently (Ferrell et al., 2008; Fritz et al., 1999; Sims, 1991; Stevens, 2008; Wotruba et al., 2001). This 'means that a company has to be more careful in how they develop such codes and procedures, so that the requirements and intended language is clear, and how they integrate the codes and procedures into the decision-making processes made use of in the organisation' (Palmer and Zakhem, 2001: 83). Employees should internalise an ethics code to impact organisational ethics, and this can be accomplished through the enforcement of standards, reprimanding/rewarding unethical/ethical behaviours, and employee discussions of workplace problems (Schwepker and Hartline, 2005; Stevens, 2008). Codes could even be framed during orientation sessions in terms of building individual virtues (Valentine and Johnson, 2005).

Organisations should also consider utilising a variety of innovative approaches tied to ethical policies. LeClair and Ferrell (2000) advocated the use of ethics games and simulations to teach employees the fundamentals of business ethics. Ferrell et al. (2008) also highlighted behavioural simulations and ethics games as techniques that can enhance understanding of ethical issues, yet they also claimed that ethics training should focus on ethical decisionmaking exercises that provide employees practice for real job-related problems. Organisations should also partner with universities so that the ethics instruction provided to students reflects the kinds of job challenges they will likely experience after graduation. For instance, panels and conferences could be arranged so that guest speakers from industry discuss important ethical issues; educational providers should also be encouraged to integrate practical discussions of business/professional codes, managerial role modelling, reporting mechanisms, and realistic ethical 
dilemmas into their ethics courses (see Simerson and Neal, 1993). Regardless of the approach implemented, ethics policies should be supported by top leaders and shaped by employee input (Jose and Thibodeaux, 1999; Sims, 1991; Stevens, 2008; White and Lam, 2000).

\section{CONCLUSION}

The study had several key limitations. For instance, the cross-sectional nature of the sample decreases the ability to make causal inferences about the relationships identified. The use of just one approach for the collection of data also raises concerns about common method bias; however, a single-factor test produced favourable results, mitigating some of this concern. Information was also collected from individuals working for just one organisation operating predominantly in single sector in one country, which may limit the generalisability of the findings to other professional populations and industries in different geographic regions. Finally, the institution's focus on health care, an inherently altruistic endeavour, might have encouraged greater attention to CSR in the organisation, thus potentially impacting the overall findings.

Future research should collect information from diverse occupational groups working in multiple organisations and/or different countries to increase the external validity of the findings. In addition, the content of ethics training and ethics codes should also be examined to determine whether different topics and approaches yield incrementally higher perceptions of organisational ethics/CSR and more positive work attitudes. Other types of ethics policies and work attitudes should also be evaluated to determine if different programs influence unique perceptions, thoughts, and feelings. For instance, the use of ethics committees, ombudsmen, and reporting policies might also affect factors such as organisational commitment and person-organisation fit.

\section{References}

Adam, A.M. and Rachman-Moore, D. (2004). 'The methods used to implement and ethical code of conduct and employee attitudes'. Journal of Business Ethics, 54, 225-244.

Adams, J.S., Tashchian, A. and Shore, T.H. (2001). 'Codes of ethics as signals for ethical behavior'. Journal of Business Ethics, 29, 199-211.

Akaah, I.P. and Lund, D. (1994). 'The influence of personal and organizational values on marketing professionals' ethical behavior'. Journal of Business Ethics, 13, 417-430.

Akaah, I.P. and Riordan, E.A. (1989). 'Judgments of marketing professionals about ethical issues in marketing research: A replication and extension'. Journal of Marketing Research, 26, 112-120.

Allen, J. and Davis, D. (1993). 'Assessing some determinant effects of ethical consulting behavior: The case of personal and professional values'. Journal of Business Ethics, 12, 449-458.

Baker, T.L., Hunt, T.G. and Andrews, M.C. (2006). 'Promoting ethical behavior and organizational citizenship behaviors: The influence of corporate ethical values'. Journal of Business Research, 59, 849-857.

Brammer, S., Millington, A. and Rayton, B. (2007). 'The contribution of corporate social responsibility to organizational commitment'. Internal Journal of Human Resource Management, 18, 1701-1719.

Cacioppe, R., Forster, N. and Fox, M. (2008). 'A survey of manager's perceptions of corporate ethics and social responsibility and actions that may affect companies' success'. Journal of Business Ethics, 82, 681-700.

Callan, V.J. (1992). 'Predicting ethical values and training needs in ethics'. Journal of Business Ethics, 11, 761-769.

Cammann, C., Fichman, M., Jenkins, G.D. and Klesh, J.R. (1979). 'The Michigan organizational assessment questionnaire', Unpublished manuscript, University of Michigan, Ann Arbor.

Cammann, C., Fichman, M., Jenkins, G.D. and Klesh, J.R. (1983). 'Assessing the attitudes and perceptions of organizational members', in $S$. Seashore, E.E. Lawler, P.H. Mirvis and C. Cammann (eds), Assessing Organizational Change: A Guide to Methods, Measures, and Practices, NY: John Wiley, 71-138.

Carroll, A.B. (1979). 'A three-dimensional conceptual model of corporate performance'. Academy of Management Review, 4, 497-505.

Cassell, C., Johnson, P. and Smith, K. (1997). 'Opening the black box: Corporate codes of ethics in their 
organizational context'. Journal of Business Ethics, 16, 1077-1093.

Chen, X., Hui, C. and Sego, D.J. (1998). 'The role of organizational citizenship behavior in turnover: Conceptualization and preliminary tests of key hypotheses'. Journal of Applied Psychology, 83, 922-931.

Chonko, L.B. and Hunt, S.D. (1985). 'Ethics and marketing management: An empirical examination'. Journal of Business Research, 13, 339-359.

Chua, F. and Rahman, A. (2011). 'Institutional pressures and ethical reckoning by business corporations'. Journal of Business Ethics, 98, 07-329.

Cleek, M.A. and Leonard, S.L. (1998). 'Can corporate codes of ethics influence behavior?' Journal of Business Ethics, 17, 619-630.

Coldwell, D., Billsberry, J., Meurs, N. and Marsh, P. (2008). 'The effects of person-organization ethical fit on employee attraction and retention: Towards a testable explanatory model'. Journal of Business Ethics, 78, 611-622.

Collett, P. (1998). 'Codes of conduct: A framework for ethics'. Australian Accountant, 68, 28-29.

Colwell, S.R., Zyphur, M.J. and Schminke, M. (2011). 'When does ethical code enforcement matter in the inter-organizational context? The moderating role of switching costs'. Journal of Business Ethics, 104, 47-58.

Crowne, D.P. and Marlowe, D. (1960). 'A new scale of social desirability independent of psychopathology'. Journal of Consulting Psychology, 24, 349-354.

Delaney, J.R. and Sockell, D. (1992). 'Do company ethics training programs make a difference? An empirical analysis'. Journal of Business Ethics, 11, 719.

Deshpande, S.P. (1996). 'The impact of ethical climate types on facets of job satisfaction: An empirical investigation'. Journal of Business Ethics, 15, 655660.

Eyun-Jung, K., Choi, H. and Lee, J. (2012). 'Does ethics statement of a public relations firm make a difference? Yes it does!' Journal of Business Ethics, 105, 267-276.

Farrell, H. and Farrell, B.J. (1998). 'The language of business codes of ethics: Implications of knowledge and power'. Journal of Business Ethics, 17, 587-601.

Ferrell, O.C., Fraedrich, J. and Ferrell, L. (2008). Business Ethics: Ethical Decision Making and Cases, Seventh edition, NY: Houghton Mifflin.

Finegan, J.E. (2000). 'The impact of person and organizational values on organizational commitment'. Journal of Occupational and Organizational Psychology, 73, 149-169.
Fischer, D.G. and Fick, C. (1993). 'Measuring social desirability: Short forms of the Marlowe-Crowne social desirability scale'. Educational and Psychological Measurement, 53, 417-424.

Fornell, C. and Larcker, D.F. (1981). 'Evaluating structural equation models with unobserved variables and measurement error'. Journal of Marketing Research, 18, 39-50.

Frisque, D.A. and Kolb, J.A. (2008). 'The effects of an ethics training program on attitude, knowledge, and transfer of training of office professionals: A treatment and control-group design'. Human Resource Development Quarterly, 19, 35-53.

Fritz, J., Harden, J.M., Arnett, R.C. and Conkel, M. (1999). 'Organizational ethical standards and organizational commitment'. Journal of Business Ethics, 20, 289-299.

Greening, D.W. and Turban, D.B. (2000). 'Corporate social performance as a competitive advantage in attracting a quality workforce'. Business and Society, 39, 254-280.

Helin, S. and Sandström, J. (2007). 'An inquiry into the study of corporate codes of ethics'. Journal of Business Ethics, 75, 253-271.

Herrbach, O. and Mignonac, K. (2007). 'Is ethical P-O fit really related to individual outcomes? A study of management-level employees'. Business and Society, 46, 304-330.

Herndon Jr., N.C., Fraedrich, J.P. and Yeh, Q. (2001). 'An investigation of moral values and the ethical content of the corporate culture: Taiwanese versus U.S. sales people'. Journal of Business Ethics, 30, 73-85.

Higgs-Kleyn, N. and Kapelianis, D. (1999). 'The role of professional codes in regulating ethical conduct'. Journal of Business Ethics, 19, 363-374.

Hunt, S.D. and Vitell. S. (2006). 'A general theory of marketing ethics: A revision and three questions'. Journal of Macromarketing 26, 143-153.

Hunt, S.D., Wood, V.R. and Chonko, L.B. (1989). 'Corporate ethical values and organizational commitment in marketing'. Journal of Marketing, $53,79-90$.

Izzo, G. (2000). 'Compulsory ethics education and the cognitive moral development of salespeople: A quasi-experimental assessment'. Journal of Business Ethics, 28, 223-241.

James Jr., H.S. (2000). 'Reinforcing ethical decision making through organizational structure'. Journal of Business Ethics, 28, 43-58.

James, L.R. and Brett, J.M. (1984). 'Mediators, moderators, and tests for mediation'. Journal of Applied Psychology, 69, 307-321. 
James, L.R., Mulaik, S.A. and Brett, J.M. (2006). 'A tale of two methods'. Organizational Research Methods, 9, 233-244.

Jaramillo, F., Mulki, J.P. and Solomon, P. (2006). 'The role of ethical climate on salesperson's role stress, job attitudes, turnover intention, and job performance'. Journal of Personal Selling and Sales Management, 26, 271-282.

Jones, G. and Kavanagh, M. (1996). 'An experimental examination of the effects of individual and situational factors on unethical behavioral intentions in the workplace'. Journal of Business Ethics, 15, 511-523.

Jose, A. and Thibodeaux, M.S. (1999). 'Institutionalization of ethics: The perspective of managers'. Journal of Business Ethics, 22, 133-143.

Kaptein, M. (2004). 'Business codes of multinational firms: What do they say?' Journal of Business Ethics, 50, 13-31.

Kaptein, M. (2008). 'Developing a measure of unethical behavior in the workplace: A stakeholder perspective'. Journal of Management, 34, 9781008.

Kaptein, M. (2009). 'Ethics programs and ethical culture: A next step in unraveling their multi-faceted relationship'. Journal of Business Ethics, 89, 261-281.

Kaptein, M. (2011a). 'From inaction to external whistleblowing: The influence of the ethical culture of organizations on employee responses to observed wrongdoing'. Journal of Business Ethics, 98, 513-5130.

Kaptein, M. (2011b). 'Toward effective codes: Testing the relationship with unethical behavior'. Journal of Business Ethics, 99, 233-251.

Kaptein, M. and Schwartz, M. (2008). 'The effectiveness of business codes: A critical examination of existing studies and the development of an integrated research model'. Journal of Business Ethics, 77, 111-127.

Kelley, S.W. and Dorsch, M. (1991). 'Ethical climate, organizational commitment, and indebtedness among purchasing executives'. Journal of Personal Selling and Sales Management, 11, 55-66.

Kim, H., Lee, M., Lee, H. and Kim, N. (2010). 'Corporate social responsibility and employee-company identification'. Journal of Business Ethics, 95, 557569.

Koh, H.C. and Boo, E.H.Y. (2001). 'The link between organizational ethics and job satisfaction: A study of managers in Singapore'. Journal of Business Ethics, 29, 309-324.

Koonmee, K., Singhapakdi, A., Virakul, B. and Lee, D. (2010). 'Ethics institutionalization, quality of work life, and employee job-related outcomes: A survey of human resource managers in Thailand'. Journal of Business Research, 63, 20-26.

Knouse, S.B. and Giacalone, R.A. (1997). 'The six components of successful ethics training'. Business and Society Review, 98, 10-13.

LeClair, D.T. and Ferrell, L. (2000). 'Innovation in experiential business training'. Journal of Business Ethics, 23, 313-322.

Maignan, I., Ferrell, O.C. and Hult, G.T.M. (1999). 'Corporate citizenship: Cultural antecedents and business benefits'. Journal of the Academy of Marketing Science, 27, 455-469.

McAlister, D.T., Ferrell, O.C. and Ferrell, L. (2005). Business and Society: A Strategic Approach to Social Responsibility, NY: Houghton Mifflin.

McCabe, D.L., Trevino, L.K. and Butterfield, K.D. (1996). 'The influence of collegiate and corporate codes of conduct on ethics-related behavior in the workplace'. Business Ethics Quarterly, 6, 461-476.

Minkes, A.L., Small, M.W. and Chatterjee. S.R. (1999). 'Leadership and business ethics: Does it matter? Implications for management'. Journal of Business Ethics, 20, 327-335.

Moser, M.R. (1988). 'Ethical conflict at work: A critique of the literature and recommendations for future research'. Journal of Business Ethics, 7, 381-387.

Mulki, J., Jaramillo, J. and Locander, W. (2009). 'Critical role of leadership on ethical climate and salesperson behaviors'. Journal of Business Ethics, 86, 125-141.

O'Donohue, W. and Nelson, L. (2009). 'The role of ethical values in an expanded psychological contract'. Journal of Business Ethics, 90, 251-263.

Palmer, D.E. and Zakhem, A. (2001). 'Bridging the gap between theory and practice: Using the 1991 federal sentencing guidelines as a paradigm for ethics training'. Journal of Business Ethics, 29, 7784.

Peterson, D.K. (2002). 'The relationship between unethical behavior and the dimensions of the ethical climate questionnaire'. Journal of Business Ethics, 41, 313-326.

Pettijohn, C., Pettijohn, L. and Taylor, A. (2008). 'Salesperson perceptions of ethics behaviors: Their influence on job satisfaction and turnover intentions'. Journal of Business Ethics, 78, 547557.

Randall, D.M. and Fernandes, M. (1991). 'The social desirability response bias in ethics research'. Journal of Business Ethics, 10, 805-817.

Rathert, C. and Phillips, W. (2010). 'Medical error disclosure training: Evidence for values-based 
ethical environments'. Journal of Business Ethics, 97, 491-503.

Rego, A., Leal, S., Cunha, M.P., Faria, J. and Pinho, C. (2010). 'How the perceptions of five dimensions of corporate citizenship and their inter-inconsistencies predict affective commitment'. Journal of Business Ethics, 94, 107-127.

Rich, G.A. (1997). 'The sales manager as a role model: Effects on trust, job satisfaction, and performance of salespeople'. Journal of the Academy of Marketing Science, 25, 319-328.

Schneider, B., Ehrhart, M.G., Mayer, D.M., Saltz, J.L. and Niles-Jolly, K. (2005). 'Understanding organization-customer links in service settings'. Academy of Management Journal, 48, 1017-1032.

Schwartz, M. (2000). 'Why ethical codes constitute an unconscionable regression'. Journal of Business Ethics, 23, 173-184.

Schwartz, M. (2001). 'The nature of the relationship between corporate codes of ethics and behaviour'. Journal of Business Ethics, 32, 247-262.

Schwepker, C.H. (1999). 'The relationship between ethical conflict, organisational commitment and turnover intentions in the salesforce', Journal of Personal Selling \& Sales Management, 19, 43-49.

Schwepker Jr., C.H. and Good, D.J. (2007). 'Sales management's influence on employment and training in developing an ethical sales force'. Journal of Personal Selling and Sales Management, 27, 325-339.

Schwepker Jr., C.H. and Hartline, M.D. (2005). 'Managing the ethical climate of customer-contact service employees'. Journal of Service Research, 7, 377-397.

Simerson, G.R. and Neal, J. (1993). 'Business ethics education: How well are we preparing our graduates for the realities of work'. American Business Review, 11, 77-83.

Sims, R.L. and Keon, T.L. (1997). 'Ethical work climate as a factor in the development of person-organization fit'. Journal of Business Ethics, 16, 1095-1105.

Sims, R.L. and Kroeck, K.G. (1994). 'The influence of ethical fit on employee satisfaction, commitment and turnover'. Journal of Business Ethics, 13, 939948.

Sims, R.R. (1991). 'The institutionalization of organizational ethics'. Journal of Business Ethics, 10, 493-506.

Sims, R.R. (1994). 'Human resource management's role in clarifying the new psychological contract'. Human Resource Management, 33, 373-382.

Singhapakdi, A. and Vitell, S.J. (1991). 'Analyzing the ethical decision making of sales professionals'.
Journal of Personal Selling and Sales Management, 11, 1-12.

Somers, M.J. (2001). 'Ethical codes of conduct and organizational context: A study of the relationship between codes of conduct, employee behavior and organizational values'. Journal of Business Ethics, 30, 185-195.

Stevens, B. (2008). 'Corporate ethics codes: Effective instruments for influencing behavior'. Journal of Business Ethics, 78, 601-609.

Stevens, J.M., Steensma, H.K., Harrison, D.A. and Cochran, P.L. (2005). 'Symbolic or substantive document? The influence of ethics codes on financial executives' decisions'. Strategic Management Journal, 26, 181-195.

Stites, J.P. and Michael, J.H. (2011). 'Organizational commitment in manufacturing employees: Relationships with corporate social performance'. Business and Society, 50, 50-70.

Strahan, R. and Gerbasi, K.C. (1972). 'Short, homogeneous versions of the Marlowe-Crowne social desirability scale'. Journal of Clinical Psychology, 28, 191-193.

Trevino, K.T. (1986). 'Ethical decision making in organizations: A person-situation interaction model'. Academy of Management Review, 11, 601617.

Trevino, L.K., Butterfield, K.D. and McCabe, D.L. (1998). 'The ethical context in organizations: Influences on employee attitudes and behaviors'. Business Ethics Quarterly, 8, 447-476.

Trevino, L.K. and Nelson, K.A. (2011). Managing Business Ethics: Strait Talk about How to Do It Right, Fifth edition, NY: John Wiley and Sons.

Turban, D.B. and Greening, D.W. (1996). 'Corporate social performance and organizational attractiveness to prospective employees'. Academy of Management Journal, 40, 658-672.

Turker, D. (2009). 'How corporate social responsibility influences organizational commitment'. Journal of Business Ethics, 89, 189-204.

Valentine, S. (2009). 'Ethics training, ethical context, and sales and marketing professionals' satisfaction with supervisors and coworkers'. Journal of Personal Selling and Sales Management, 29, 227-242.

Valentine, S. and Barnett, T. (2002). 'Ethics codes and sales professionals' perceptions of their organizations' ethical values'. Journal of Business, 40, 191-200.

Valentine, S. and Barnett, T. (2003). 'Ethics code awareness, perceived ethical values, and organizational commitment'. Journal of Personal Selling and Sales Management, 23, 359-367. 
Valentine, S. and Barnett, T. (2007). 'Perceived organizational ethics and the ethical decisions of sales and marketing personnel'. Journal of Personal Selling and Sales Management, 27, 373-388.

Valentine, S. and Fleischman, G. (2004). 'Ethics training and businesspersons' perceptions of organizational ethics'. Journal of Business Ethics, 52, 381-390.

Valentine, S. and Fleischman, G. (2008). 'Ethics programs, perceived corporate social responsibility and job satisfaction'. Journal of Business Ethics, 77, 159-172.

Valentine, S. and Godkin, L. (2009). 'Ethics, social responsibility, and ethical reasoning in an education-based health science center: When doing good results in good employees'. Journal of Leadership, Accountability and Ethics, 7, 1-17.

Valentine, S., Godkin, L., Fleischman, G.M. and Kidwell, R. (2011). 'Corporate ethical values, group creativity, job satisfaction, and turnover intention: The impact of work context on work response'. Journal of Business Ethics, 98, 353-372.

Valentine, S., Godkin, L. and Lucero, M. (2002). 'Ethical context, organizational commitment, and personorganization fit'. Journal of Business Ethics, 41, 349-360.

Valentine, S., Godkin, L. and Varca, P. (2010). 'Role conflict, mindfulness, and organizational ethics in an education-based healthcare institution'. Journal of Business Ethics, 94, 455-469.

Valentine, S., Greller, M.M. and Richtermeyer, S.B. (2006). 'Employee job response as a function of ethical context and perceived organization support'. Journal of Business Research, 59, 582-588.

Valentine, S. and Johnson, A. (2005). 'Codes of ethics, orientation programs, and the perceived importance of employee incorruptibility'. Journal of Business Ethics, 61, 45-53.

Viswesvaran, C. and Deshpande, S.P. (1996). 'Ethics, success, and job satisfaction: A test of dissonance theory in India'. Journal of Business Ethics, 15, 1065-1069.

Viswesvaran, C., Deshpande, S.P. and Joseph, J. (1998). 'Job satisfaction as a function of top management support for ethical behavior'. Journal of Business Ethics, 17, 365-371.

Vitell, S.J. and Davis, D.L. (1990). 'The relationship between ethics and job satisfaction: An empirical investigation'. Journal of Business Ethics, 9, 489494.

Waples, E.P., Antes, A.L., Murphy, S.T., Connelly, S. and Mumford, M.D. (2009). 'A meta-analytic investigation of business ethics instruction'. Journal of Business Ethics, 87, 133-151.

Weaver, G.R. (2004). 'Ethics and employees: Making the connection'. Academy of Management Perspective, 18, 121-125.

Weaver, G.R., Trevino, L.K. and Cochran, P.L. (1999a). 'Corporate ethics programs as control systems: Influences of executive commitment and environmental factors'. Academy of Management Journal, 42, 41-57.

Weaver, G.R., Trevino, L.K. and Cochran, P.L. (1999b). 'Integrated and decoupled corporate social performance: Management commitments, external pressures, and corporate ethics practices'. Academy of Management Journal, 42, 539-552.

Weaver, G.R., Trevino, L.K. and Cochran, P.L. (1999c). 'Corporate ethics practices in the mid-1990's: An empirical study of the fortune 1000'. Journal of Business Ethics, 18, 283-294.

Wells, D. and Schminke, M. (2001). 'Ethical development and human resources training: An integrative framework'. Human Resource Management Review, 11, 135-158.

White, L.P. and Lam, L.W. (2000). 'A proposed infrastructure model for the establishment of organizational ethical systems'. Journal of Business Ethics, 28, 35-42.

Wood, D.J. (1991). 'Corporate social performance revisited'. Academy of Management Review, 16, 691-718.

Wotruba, T.R., Chonko, L.B. and Loe, T.W. (2001). 'The impact of ethics code familiarity on manager behavior'. Journal of Business Ethics, 33, 59-69.

Zenisek, T.J. (1979). 'Corporate social responsibility: A conceptualization based on organizational literature'. Academy of Management Review, 4, 359-368. 